\title{
Pengujian Filter Fisik (Slow Sand Filter) Untuk Menurunkan Kadar Pestisida Golongan Organoklorin
}

\author{
Siska Rasiska1, Aditya Bintan Pratama ${ }^{2}$ dan Fitri Widiantini ${ }^{1}$ \\ ${ }^{1}$ Staff Pengajar Departemen Hama dan Penyakit Tumbuhan Fakultas Pertanian \\ Universitas Padjadjaran \\ ${ }^{2}$ Mahasiswa Program Studi Agroteknologi, Fakultas Pertanian, Universitas Padjadjaran \\ Jl. Raya Bandung Sumedang Km 21 Jatinangor
}

Korespondensi: siskarasiska@yahoo.com; adityabintanpratama@gmail.com

\begin{abstract}
Organochlorine pesticide is one of the pesticide that has high persistency and toxic. One of the attempt to degrade organochlorine pesticide using cheaper and easier way is using the slow sand filter technology. The research aimed to test the slow sand filter and to obtain the best filter media combination for degrading organochlorine pesticide. The experiment was conducted at the Laboratory of Pesticide and Toxicology, Laboratory of Plant Protection Biotechnology and Laboratory of Chemical and Soil Fertility, Faculty of Agriculutre, Padjadjaran Univeristy from December 2016 - May 2017. The experimental design used the observative and descriptive design with 8 treatments and repeated twice. P1 (activated carbon and gravel), P2 (sand and gravel), P3 (silica sand and gravel), P4 (activated carbon and zeolite), P5 (sand and zeolite), P6 (silica sand and zeolite), P7 (activated carbon, silica sand and zeolite), P8 (activated carbon, sand and gravel). The result showed that all treatments of slow sand filter were able to degrade organochlorine pesticide and the best filter media combination was from P7 with ability to degrade the pesticide level by $82,86 \%$.
\end{abstract}

Key words: slow sand filter, activated carbon, silica sand, sand, gravel, zeolite

\section{PENDAHULUAN}

Pestisida adalah zat atau senyawa kimia, zat pengatur dan perangsang tumbuh, bahan lain, serta organisme renik, atau virus yang digunakan untuk melakukan perlindungan tanaman (UU No 12 tahun 1992 tentang Sistem Budidaya Tanaman). Pestisida organoklorin merupakan salah satu jenis pestisida yang digunakan oleh para petani di Indonesia (Yuantari dkk., 2013). Walaupun, pestisida organoklorin ini sudah dilarang penggunaannya namun masih ditemukan adanya residu pestisida di lingkungan.

Rustia (2009) menyatakan bahwa organoklorin merupakan senyawa yang terdiri dari atom karbon, khlor dan hidrogen yang terkadang terdapat oksigen dengan formula umum $\mathrm{C}_{\mathrm{x}} \mathrm{H}_{\mathrm{y}} \mathrm{Cl}_{\mathrm{z}}$ (Gambar 1). Pestisida organoklorin merupakan pestisida hidrokarbon berklorin Insektisida organoklorin dikelompokkan menjadi tiga golongan yaitu (1) DDT dan analognya, misalnya BHC, dicofol,
Klorobenzilat, TDE dan metoxychlor, (2) senyawa siklodien, misalnya aldrin, dieldrin, endrin, endusulfan dan heptaklor, dan, (3) terpena berklor, misalnya toksafen. Racun ini bersifat mengganggu susunan syaraf dan larut dalam lemak (Yuantari dkk., 2013).

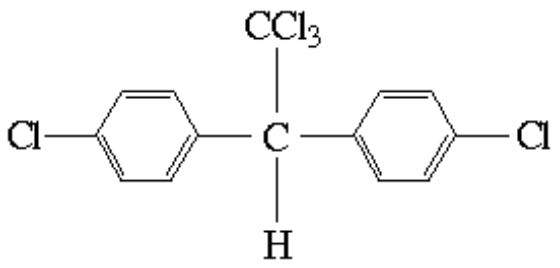

Gambar 1 Struktur kimia salah satu pestisida golongan organoklorin

Menurut Sari (2014) herbisida 2,4 D merupakan salah satu herbisida golongan organoklorin yang masih banyak digunakan di Indonesia. Struktur kimia 2,4 D ditampilkan pada Gambar 2. Menurut Peller dkk. (2004) dalam Elvinawati (2009), menyatakan bahwa 
herbisida 2,4 D di alam dalam jumlah yang banyak akan sangat mengganggu.

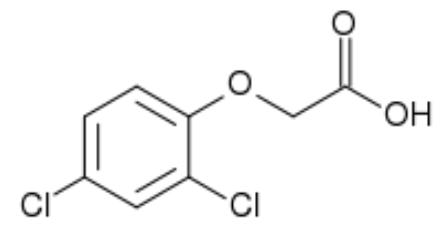

Gambar 2 Struktur kimia herbisida Asam 2,4 Diklorofenoksiasetat (2,4 D). Sumber : Aini (2014)

Pestisida organoklorin ini mempunyai tingkat persistensi di alam yang sangat tinggi (Hadi dkk., 2009). Akibat dari sifat persistensi yang tinggi, tidak reaktif dan stabil di alam menyebabkan pestisida ini sulit terdegradasi dan dapat mencemari air, tanah dan udara. Penggunaan pestisida organoklorin dapat mengontaminasi pengguna secara langsung dan menyebabkan keracunan (Ramadhani dan Oginawati, 2011). Pestisida organoklorin tetap bersifat toksik dan kronik karena tidak langsung menyebabkan kematian namun kandungan pestisida ini dapat terakumulasi dalam jaringan tubuh (Indraningsih dan Widiastuti ,1998).

Pencemaran pestisida organoklorin banyak ditemukan pada endapan (sedimen) dan perairan. Hasil analisis organoklorin pada air jika dibandingkan dengan PP No 82 Tahun 2001 menunjukkan bahwa pada beberapa titik di Waduk Saguling kandungan organoklorin jenis DDT dan aldrin melebihi dari baku mutu yang telah ditentukan (Rahmawati dan Oginawati, 2012).

Hutagalung dkk. (1997) dalam Munawir (2005) melaporkan ditemukannya kadar pestisida organoklorin yang tinggi pada muara sungai di pantai timur Sumatra yaitu di Muara Kuala dan Kuala Tungkal (Jambi), Muara Sungai Musi (Palembang), dan bahkan terlihat tanda-tanda penggunaan pestisida organoklorin di Muara Siak (Riau). Kualitas air yang digunakan untuk kegiatan pertanian diatur dalam PP No 82/2001 tentang "Pengelolaan Kualitas Air dan Pengendalian Pencemaran Air". Di dalam PP tersebut bahwa air yang digunakan untuk pertanian masuk ke dalam kelas air II-IV dengan batas maksimum untuk klorin sebesar 0,03 mg/L.

Penggunaan filter fisik sebagai salah satu cara untuk mengolah limbah perairan paling sederhana (Fandri dkk., 2011). Pengolahan dengan filter fisik ini menggunakan beberapa bahan-bahan yang aktif untuk mengolah air yang tercemar. Bahan yang ada di dalam filter fisik yaitu berupa saringan, pasir, kerikil, tambahan karbon aktif atau bioremediator. Saringan pasir lambat merupakan saringan dengan cara penggunaan yang mudah dan harganya yang terjangkau. Menurut Josephinne dkk. (2010), slow sand filter dengan media pasir dapat menurunkan kekeruhan hingga $76 \%$, warna $46 \%$ dan zat organik $32 \%$.

Penelitian yang dilakukan oleh Chrisafitri dan Karnaningroem (2012) menyebutkan bahwa saringan pasir lambat dengan media karbon aktif, pasir dan kerikil dapat mengolah air limbah pencucian mobil yang banyak berisi zat kimia (surfaktan). Karbon aktif merupakan material yang memiliki pori-pori besar dan dapat menyerap apa saja yang dilaluinya (Roop Chand, 2005 dalam Chrisafitri dan Karnaningroem, 2012). Menurut Sari (2011), karbon aktif lebih banyak menghilangkan zat pencemar jika dibandingkan dengan karbon biasa. Pori-pori dari karbon aktif ini pun lebih besar sehingga dapat menyerap zat-zat yang melewati karbon aktif. Terdapat dua jenis karbon aktif yaitu karbon aktif berbentuk granular dan blok. Awaludin (2007) dalam Sari (2011), menyebutkan bahwa karbon aktif berbentuk granular lebih efektif dalam menghilangkan rasa, klorin dan bahan organik terhalogenasi.

Pasir silika dan zeolit yang mempu-nyai kemampuan dalam adsorbsi pencemar organik dan logam. Mahdi dan Hadi (2011) menyebutkan bahwa filter fisik pasir dan kerikil dapat menurunkan kadar pencemar organik, surfaktan dan bakteri E.coli hingga berada di bawah batas aman yang ditentukan pemerintah. Berdasarkan hasil penelitian Saifudin dan Astuti (2005), menunjukkan 
bahwa kombinasi zeolit-karbonaktif dengan ketebalan $60 \mathrm{~cm}$ mampu menurunkan kadar Fe sebesar 90,73\%.

Handayani (2011) dalam Handarbeni (2013), menunjukkan bahwa kombinasi pasir silika dan zeolit dengan ketebalan $60 \mathrm{~cm}$ mampu menurunkan kadar Fe 95,42\%. Zilfa dkk. (2013) menyatakan bahwa zeolit dengan sifat adsorbannya dapat menurunkan kadar $10 \mathrm{mg} / \mathrm{L}$ pestisida Permetrin (golongan Pyretroid) hingga 82,77\%. Sementara Mahdi dan Hadi (2011) menyatakan bahwa pasir berfungsi sebagai penyaring fisik dan kerikil sebagai lapisan penyangga berguna untuk mencegah keluarnya pasir menuju keran outlet.

\section{METODE PENELITIAN}

Penelitian ini dilaksanakan di Laboratorium Pestisida dan Toksikologi Lingkungan dan Laboratorium Bioteknologi Proteksi Tanaman Departemen Hama dan Penyakit Tumbuhan. Analisis kimia dilakukan pada Laboratorium Kimia dan Kesuburan Tanah Departemem Ilmu Tanah dan Sumber Daya Lahan Fakultas Pertanian Universitas Padjadjaran, Jatinangor. Penelitian ini dilaksanakan pada bulan Desember 2016 Mei 2017.

Alat yang digunakan dalam percobaan ini diantaranya adalah botol plastik, alat analisis kandungan klorin dengan titrasi Argentometri metode Mohr, pH meter, alat tulis, dan alat pembuatan reaktor filter berupa pipa dan keran outlet, selang plastik, wadah filter berbahan PVC dengan diameter $15 \mathrm{~cm}$.

Bahan yang digunakan dalam percobaan ini diantaranya adalah air, media filter berupa karbon aktif berbentuk granul, pasir dan pasir silika dengan ukuran $\pm 0,15-1 \mathrm{~mm}$, kerikil ukuran $\pm 1 \mathrm{~cm}-4 \mathrm{~cm}$ dan zeolit ukuran $\pm 6,3$ $\mathrm{mm}$, dan pestisida organoklorin (bahan aktif 2,4 D dengan nama dagang Ally Plus 77 WP).

Penelitian ini merupakan pengujian terhadap efektifitas berbagai media filter. Komposisi kombinasi media filter yang dicobakan pada penelitian meliputi:
P1 : Karbon aktif dan Kerikil

P2 : Pasir dan Kerikil

P3 : Pasir Silika dan Kerikil

P4 : Karbon Aktif dan Zeolit

P5 : Pasir dan Zeolit

P6 : Pasir Silika dan Zeolit

P7 : Karbon Aktif, Pasir Silika dan Zeolit

P8 : Karbon Aktif, Pasir dan Kerikil

Setiap urutan penulisan pada perlakuan menunjukkan susunan media secara vertikal dari lapisan atas menuju lapisan media paling dasar. Perlakuan ini diulangi sebanyak dua kali (duplo).

Penelitian ini dapat dibagi menjadi beberapa tahapan, yaitu:

\section{a. Penyusunan Filter Fisik}

Filter fisik terbuat dengan bahan PVC diameter $15 \mathrm{~cm}$ dengan tinggi $100 \mathrm{~cm}$ dengan berbagai media sesuai pada perlakuan. Pada penelitian ini digunakan 2 kelompok media yaitu media filter bagian atas dan media filter bagian bawah (media penyangga). Media filter bagian atas terdiri atas karbon aktif, pasir silika dan pasir, dan untuk media penyangga terdiri atas kerikil dan zeolit (Gambar 3).

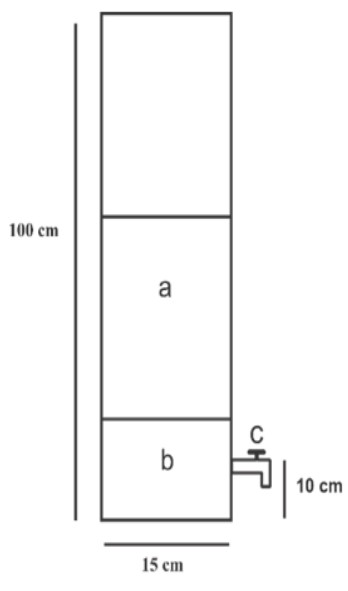

a

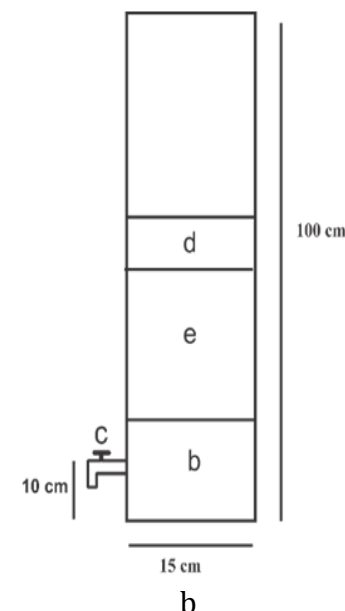

b
Keterangan:

a : Media filter setinggi $40 \mathrm{~cm}$

b : Media penyangga setinggi $20 \mathrm{~cm}$

c : Keran outlet setinggi $10 \mathrm{~cm}$

$\mathrm{d}$ : Media filter setinggi $10 \mathrm{~cm}$

e : Media filter setinggi $30 \mathrm{~cm}$

Gambar 3 Layout filter fisik; 2 jenis media (a) dan 3 jenis media (b) 
Total media yang digunakan memenuhi maksimal $60 \mathrm{~cm}$ dari tinggi filter. Pada filter dengan 3 jenis media, maka susunan filter yaitu media filter bagian atas pertama menempati $10 \mathrm{~cm}$, media filter bagian atas kedua $30 \mathrm{~cm}$ dan media penyangga menempati $20 \mathrm{~cm}$ dari tinggi tabung filter. Kombinasi media filter pada perlakuan dibuat dengan menukar media filter pada kelompok media yang sama. Filter ini ditambahkan outlet keran dengan ketinggian $10 \mathrm{~cm}$ dari dasar. Penampungan larutan hasil filtrasi ditampung dalam jirigen plastik

\section{b. Pembuatan Larutan Sumber}

Larutan sumber merupakan larutan beban limbah yang akan difilitrasi. Pada penelitian ini beban limbah dengan kandungan pestisida dibuat dengan melarutkan pestisida ke dalam $7 \mathrm{~L}$ air untuk setiap perlakuan. Konsentrasi pestisida yang ditambahkan ke dalam air mengacu pada $\mathrm{LC}_{50}$ dari pestisida Ally Plus 77 WP yaitu $200 \mathrm{mg} / \mathrm{L}$ pada ikan rainbow trout (PT.Dupon, 2012), sehingga pestisida yang dilarutkan untuk setiap perlakuan yaitu sebesar $1,4 \mathrm{~g}$. Penggunaan konsentrasi pestisida pada penelitian ini mengacu pada penelitian sebelumnya.

\section{c. Pengamatan dan Analisis Kandungan Air}

Pengamatan yang dilakukan adalah dengan menganalisis kandungan air dilakukan pada larutan sebelum diproses dan setelah proses filtrasi. Larutan sebelum proses dan setelah proses filtrasi ditampung dalam botol plastik sesuai dengan perlakuan sehingga didapatkan total 17 botol untuk dianalisis $\mathrm{pH}$ pada Laboratorium Bioteknologi Proteksi Tanaman Departemen Hama Penyakit Tumbuhan dan kandungan klorin pada Laboratorium Kimia dan Kesuburan Tanah Departemem Ilmu Tanah dan Sumber Daya Lahan Fakultas Pertanian Universitas Padjadjaran.

Pengamatan dilakukan terhadap 17 botol sample yang terdiri atas 1 botol larutan sumber dan 16 botol larutan hasil filtrasi dari seluruh perlakuan. Parameter pengamatan dan analisis kandungan air meliputi:

1. Perhitungan kadar klorin (Cl) pestisida organoklorin dari setiap perlakuan

Kadar klorida $\left(\mathrm{Cl}^{-}\right)$dihitung dengan metode argentometri berupa titrasi dari larutan AgNO3, dimana akan terbentuk endapan merah bata dari klorida yang bereaksi. Perhitungan kadar klorida dilakukan dengan membandingkan volume titrasi $\mathrm{AgNO}_{3}$ dari larutan baku klorin $1.000 \mathrm{ppm}$ terhadap volume titrasi $\mathrm{AgNO}_{3}$ yang digunakan pada setiap sampel perlakuan. Dengan cara tersebut ditemukan besaran klorin dalam setiap larutan.

2. Nilai pH larutan pada setiap perlakuan Pengukuran nilai $\mathrm{pH}$ dilakukan pada air tanpa diberi perlakuan apapun, larutan sumber dan larutan hasil filtrasi dari setiap perlakuan. Pengukuran $\mathrm{pH}$ langsung dilakukan setelah diperoleh sampel dari air yang digunakan di laboratorium Pestisida dan Toksikologi Lingkungan, larutan sumber dan larutan hasil filtrasi dari seluruh perlakuan. Pengkuran $\mathrm{pH}$ dilakukan dengan $\mathrm{pH}$ meter stasionery dengan merk Hanna model pH 211.

3. Lama waktu filtrasi

Pengukuran Lama waktu filtrasi dilakukan dengan mengamati dan mencatat lama waktu filtrasi semenjak dibukanya keran outlet hingga tidak ada larutan hasil filtrasi yang keluar dari filter. Penentuan kecepatan filtrasi dilakukan dengan menentukan besaran debit dari setiap filter lalu dilakukan perhitungan kecepatan filtrasi.

\section{HASIL DAN PEMBAHASAN}

\subsection{Hasil Pengujian Filter Fisik dengan Berbagai Media terhadap Kadar Pestisida Organoklorin}

Penurunan kadar $\mathrm{Cl}$ setiap perlakuan ditampilkan guna mempermudah pembacaan 
kinerja filter terhadap penutunan kadar $\mathrm{Cl}$. Perubahan kadar $\mathrm{Cl}$ dihitung dari selisih larutan sumber berpestisida dengan larutan setelah proses filtrasi pada setiap perlakuan. Perubahan kadar $\mathrm{Cl}$ sebelum dan sesudah pada setiap perlakuan ditampilkan pada Tabel 1.

Tabel 1 Kadar $\mathrm{Cl}$ dan penurunannya setelah diberi perlakuan

\begin{tabular}{cccc}
\hline & \multicolumn{3}{c}{ Kadar Cl } \\
hasil & $\begin{array}{c}\text { Penurunan } \\
\text { ferlakuan } \\
\text { filtrasi } \\
\text { (ppm) }\end{array}$ & $\begin{array}{c}\text { Penurunan } \\
\text { (ppm) }\end{array}$ & $\begin{array}{c}\text { Kadar Cl } \\
\text { (\%) }\end{array}$ \\
\hline P1 & 16,00 & 5,54 & 25,71 \\
P2 & 17,54 & 4,00 & 18,57 \\
P3 & 11,54 & 10,00 & 46,43 \\
P4 & 10,62 & 10,92 & 50,71 \\
P5 & 9,38 & 12,15 & 56,43 \\
P6 & 8,62 & 12,92 & 60,00 \\
P7 & 3,69 & 17,85 & 82,86 \\
P8 & 5,38 & 16,15 & 75,00 \\
\hline Larutan & & & \\
Sumber & 21,54 & & \\
(Sebelum & & & \\
Filtrasi) & & & \\
\hline
\end{tabular}

Perlakuan P2 (pasir dan kerikil) memiliki rata-rata penurunan kadar $\mathrm{Cl}$ paling kecil dibandingkan dengan perlakuan lain. Hal ini diduga karena secara fisik, pasir dan kerikil merupakan media dengan kemampuan penyaring tanpa kemampuan kimia untuk menyerap $\mathrm{Cl}$. Pasir dan kerikil merupakan media yang memiliki ukuran besar, sehingga hanya mampu menjadi penyaring bagi zat yang berukuran besar. Penambahan media filter tersebut dengan karbon aktif (P8) menunjukkan tingkat penurunan kadar $\mathrm{Cl}$ hingga 75\% yang lebih besar dibandingkan dengan P2 yaitu sebesar 18,57\%.

Secara fisik, karbon aktif diketahui memiliki ruang pori sangat banyak dengan ukuran tertentu. Pori-pori ini dapat menangkap partikel-partikel sangat halus (molekul) dan menjebaknya disana. Satu gram karbon aktif, pada umumnya memiliki luas permukaan seluas $500-1.500 \mathrm{~m}^{2}$, sehingga sangat efektif dalam menangkap partikel- partikel yang sangat halus berukuran 0,010,0000001 mm (Anonim, 2002 dalam Yudha, 2009).

Secara kimiawi, karbon aktif juga memiliki kemampuan yang tinggi untuk mengabsorpsi zat kimia, baik yang berwarna ataupun berbau (Sari, 2011), sehingga dapat menurunkan zat organik, bau, rasa, polutan mikro dan menjernihkan air (Istiklaili, 2008). Awaludin (2007) dalam Sari (2011), menyebutkan bahwa karbon aktif berbentuk granular lebih efektif dalam menghilangkan rasa, klorin dan bahan organik terhalogenasi

Tabel 1 juga menunjukkan bahwa perlakuan P7 (karbon aktif, pasir silika, zeolite) memiliki nilai rata-rata penurunan kadar $\mathrm{Cl}$ terbesar dibandingkan dengan perlakuan lainnya, yaitu sebesar $82,86 \%$. Komposisi filter fisik dengan media karbon aktif, pasir silika dan zeolit memiliki kemampuan untuk dapat menyaring secara fisik dan mengabsorpsi secara kimiawi. Ukuran media yang kecil dan berpori menyebabkan semua media tersebut mampu menyerap berbagai zat kimia, diantaranya $\mathrm{Cl}$.

Pasir kuarsa mempunyai komposisi gabungan dari $\mathrm{SiO}_{2}, \mathrm{Fe}_{2} \mathrm{O}_{3}, \mathrm{Al}_{2} \mathrm{O}_{3}, \mathrm{TiO}_{2}, \mathrm{CaO}$, $\mathrm{MgO}$, dan $\mathrm{K}_{2} \mathrm{O}$, berwarna putih bening atau warna lain tergantung pada senyawa pengotornya, kekerasan 7 (skala Mohs), berat jenis 2,65, titik lebur $17-150^{\circ} \mathrm{C}$, bentuk kristal hexagonal, panas spesifik 0,185 (Kusnaedi, 2010). Media silika berfungsi menghilangkan bakteri, bau, rasa, warna dan besi (Istiklaili, 2008). Menurut Central Pollution Control Board (2012), menyebutkan bahwa pemberian pasir silika dapat memengaruhi penurunan kadar $\mathrm{Cl}$ pada larutan.

Zeolit adalah mineral kristal alumina silika tetrahidrat berpori yang mempunyai struktur kerangka tiga dimensi, terbentuk oleh tetrahedral $\left[\mathrm{SiO}_{4}\right]^{4-}$ dan $\left[\mathrm{AlO}_{4}\right]^{5-}$ yang saling terhubungkan oleh atom-atom oksigen sedemikian rupa, sehingga membentuk kerangka tiga dimensi terbuka yang mengandung kanal-kanal dan rongga-rongga, yang didalamnya terisi oleh ion-ion logam, biasanya adalah logam-logam alkali atau alkali 
tanah dan molekul air yang dapat bergerak bebas (Chetam, 1992 dalam Lestari, 2010). Kurniawan dkk. (2014) menambahkan bahwa penggunaan zeolit dapat menurunkan kadar klorida sebesar $0,85 \mathrm{~g} / \mathrm{L}$.

\subsection{Tingkat Keasaman (pH)}

Pengujian filter fisik dengan berbagai media memiliki pengaruh terhadap tingkat keasaman, lama waktu dan kecepatan filtrasi, seperti disajikan pada Tabel 2. Ketiga indikator kimia dan fisik ini juga terkait satu sama lain sebagai satu kesatuan, dan diduga juga memiliki keterkaitan dengan kadar $\mathrm{Cl}$.

Tabel 2 Nilai tingkat keasaman (pH) pada

\begin{tabular}{lc}
\hline \multicolumn{1}{c}{ Perlakuan } & $\mathrm{pH}$ \\
\hline Air & 7,73 \\
P1 (Karbon Aktif \& Kerikil) & 7,99 \\
P2 (Pasir \& Kerikil) & 7,95 \\
P3 (Pasir Silika \& Kerikil) & 6,71 \\
P4 (Karbon Aktif \& Zeolit) & 6,48 \\
P5 (Pasir \& Zeolit) & 7,84 \\
P6 (Pasir Silika \& Zeolit) & 6,50 \\
P7 (Karbon Aktif, Pasir Silika \& & 6,59 \\
Zeolit) & 7,62 \\
P8 (Karbon Aktif, Pasir \& Kerikil) & 7,85 \\
\hline Larutan Sumber (Sebelum & \\
Filtrasi) & \\
\hline
\end{tabular}

Tabel 2 menunjukkan bahwa terjadi penurunan $\mathrm{pH}$ pada larutan $\mathrm{Cl}$ sebelum perlakuan dan setelah perlakuan. Penurunan $\mathrm{pH}$ terbesar terjadi pada larutan $\mathrm{Cl}$ dengan perlakuan P4 (karbon aktif dan zeolite), yaitu sebesar 1,35. Hal ini diduga karena karbon aktif dan zeolite memiliki kemampuan untuk menurunkan $\mathrm{pH}$. Hal ini sejalan dengan pernyataan Mifbakhuddin (2010), yang menyatakan bahwa secara kimiawi, penggunaan media karbon aktif dengan penyerapan $\mathrm{Cl}$ yang baik akan menurunkan $\mathrm{pH}$.

Penambahan zeolite yang fungsinya sama dengan karbon aktif yang mampu menyerap senyawa kimiawi, hal ini akan meningkatkan kemampuan zeolit untuk menurunkan $\mathrm{pH}$. Akan tetapi, perlakuan P1 (karbon aktif dan kerikil) menunjukkan terjadi peningkatan $\mathrm{pH}$ sebesar 0,14. Hal ini menunjukkan bahwa walaupun karbon aktif dapat menurunkan $\mathrm{pH}$, tetapi apabila ditambahkan dengan kerikil yang tidak memiliki kemampuan kimiawi, maka akan terjadi sebaliknya.

Mengacu kepada PP No 82 tahun 2001 tentang pengelolaan kualitas air dan pengendalian pencemaran air, $\mathrm{pH}$ yang baik untuk kelas air I-III yaitu berada pada kisaran pH 6-9 dan pada kelas air IV yaitu 5-9, maka tingkat keasaman $(\mathrm{pH})$ air pada seluruh perlakuan dapat dikategorikan aman bagi mahluk hidup.

\subsection{Lama waktu dan Kecepatan Filtrasi}

Indikator lama waktu dan kecepatan filtrasi menunjukan pada syarat kelayakan suatu alat filter yang tergolong lambat (slow sand filter). Berdasarkan hasil pengujian lama waktu filtrasi dan kecepatan filtrasi (Tabel 3) media yang sesuai untuk filter pasir lambat adalah P6, yaitu sebesar 38 menit 48 detik dan 0,61. Berbeda dengan perlakuan P1 dengan lama waktu filtrasi 27 menit 00 detik dan kecepatan filtrasi 0,88 yang tergolong pada media tercepat. Menurut Endahwati dkk. (2009) dalam Wibowo dan Putra (2013), menyatakan bahwa ukuran partikel yang besar mengakibatkan porositas tinggi sehingga rata-rata lama waktu filtrasi berjalan lebih cepat.

Tabel 3 Nilai tingkat keasaman, lama waktu dan kecepatan filtrasi

\begin{tabular}{ccc}
\hline Perlakuan & $\begin{array}{c}\text { Lama Waktu } \\
\text { Filtrasi }\end{array}$ & $\begin{array}{c}\text { Kecepatan } \\
\text { Filtrasi } \\
\text { (km/jam) }\end{array}$ \\
\hline P1 & $27^{\prime} 00^{\prime \prime}$ & 0,88 \\
P2 & $34^{\prime} 38^{\prime \prime}$ & 0,69 \\
P3 & $36^{\prime} 51^{\prime \prime}$ & 0,65 \\
P4 & $36^{\prime} 48^{\prime \prime}$ & 0,65 \\
P5 & $37^{\prime} 22^{\prime \prime}$ & 0,64 \\
P6 & $38^{\prime} 48^{\prime \prime}$ & 0,61 \\
P7 & $38^{\prime} 26^{\prime \prime}$ & 0,62 \\
P8 & $35^{\prime} 57^{\prime \prime}$ & 0,66 \\
\hline
\end{tabular}

Longsdon dkk. (2002) dalam Astari dan Iqbal (2009), menyebutkan bahwa kecepatan 
filtrasi dari saringan pasir lambat biasanya berkisar antara 0,1-0,3 m/jam. Menurut SNI (2008), kecepatan filtrasi harus berada pada rentang 0,1-0,4 m/jam. Apabila mengacu pada SNI, maka semua perlakuan tidak memiliki kelayakan untuk dijadikan sebagai filter pasir lambat. Jika mengacu pada syarat SNI dimana kecepatan filtrasi berada pada 0,1-0,4 m/jam maka lama waktu filtrasi pada setiap perlakuan harus berada pada rentang 59 menit-3 jam, sedangkan lama waktu filtrasi terlama berada pada perlakuan P6 dengan waktu 38 menit 48 detik.

Menurut Endahwati dkk. (2009) dalam Wibowo dan Putra (2013), ukuran (diameter) butiran media berpengaruh pada porositas, rate filtrasi dan daya saring. Tebal tidaknya media akan mempengaruhi lama pengaliran dan besar daya saring. Media yang ditempatkan diatas media penyangga jika diurutkan berdasarkan ukuran partikel dari ukuran terkecil sampai terbesar yaitu pasir silika dengan ukuran partikel 18-20 mesh atau $\pm 0,8-1 \mathrm{~mm}$, pasir dengan ukuran partikel \pm 8-10 mesh atau 2-2,3 $\mathrm{mm}$ dan karbon aktif sebesar \pm 6 mesh atau $3 \mathrm{~mm}$. Pada media penyangga urutan partikel terkecil yaitu zeolit dengan ukuran partikel 4 mesh atau $\pm 4-5 \mathrm{~mm}$ lalu diikuti dengan kerikil dengan ukuran partikel $\pm 1-2 \mathrm{~cm}$.

\section{KESIMPULAN}

Penggunaan filter fisik dengan berbagai komposisi media mampu menurunkan kadar Cl. Perlakuan dengan karbon aktif, pasir silika dan zeolit merupakan perlakuan paling efektif dalam menurunkan kandungan pestisida organoklorin dengan penurunan sebesar $82,86 \%$.

\section{DAFTAR PUSTAKA}

Astari, S. dan R. Iqbal. 2009. Kehandalan Saringan Pasir Lambat dalam Pengolahan Air. Institut Teknologi Bandung. Bandung.

Central Pollution Control Board. 2012. Status of water treatment plant in India. Ministry of Enviroment and Forest. Tersedia online di
http://cpcb.ni.in/upload/NewItems/Ne wItem_103_statusofwaterqualitypackag e.pdf. [9 Juli 2017]

Hadi, M., T. Udi, dan R. Rully. 2009. Biologi Insekta Entomologi. Graha Ilmu. Yogyakarta.

Indraningsih dan R. Widiastuti. 1998. Residu pestisida organoklorin serta kemungkinan bahayanya pada ternak. WARTAZOA. 7 (2): 55-60.

Kurniawan, A., B. Rahadi, dan L. D. Susanawati. 2014. Studi pengaruh zeolit alam termodifikasi HTDMA terhadap penurunan salinitas air payau. Jurnal Sumber Daya Alam dan Lingkungan. 1 (2): 31-37.

Mifbakhuddin. 2010. Pengaruh Ketebalan Karbon Aktif Sebagai Media Filter Terhadap Penurunan Kesadahan Air Sumur Artesis. Eksplanasi. 5 (2): 1-11

PT DuPont Agricultural Products Indonesia. 2012. Lembar Keselamatan Kerja Ally Plus 77 WP. Jakarta.

Ramadhani, N.W. dan K. Oginawati. 2011. Residu Insektisida Organooklorin Di Persawahan SUB DAS Citarum Hulu. Institut Teknologi Bandung. Bandung.

Sari, N.M. 2011. Kinerja Biosand Filter untuk Pengolahan Air Minum Ditinjau Terhadap Parameter Kekeruhandan Besi. Institut Teknologi Sepuluh November. Surabaya.

Standar Nasional Indonesia. 2008. SNI 3981:2008 Perencanaan Instalasi Saringan Pasir Lambat. Badan Standarisasi Nasional Indonesia.

Wibowo, A.Y. dan A. Putra. 2013. Pengaruh Ukuran Partikel Batu Apung terhadap Kemampuan Serapan Cairan Limbah Logam Berat. Jurnal Fisika Unand. 2 (3): 155-161.

Yuantari, M.G.C., B. Widiarnako dan H.R. Sunoko. 2013. Tingkat pengetahuan petani dalam menggunakan pestisida (Studi kasus di Desa Curut Kecamatan Penawangan Kabupaten Grobogan). Prosiding Seminar Nasional Pengelolaan Sumberdaya Alam dan Lingkungan. Hal: 142-148. 